\title{
sciendo

\section{Evaluation of the Environmental Engineering Study Programme at University}

\author{
Jelena PUBULE ${ }^{1 *}$, Antra KALNBALKITE ${ }^{2}$, Erika TEIRUMNIEKA ${ }^{3}$, Dagnija BLUMBERGA $^{4}$ \\ ${ }^{1-4}$ Institute of Energy Systems and Environment, Riga Technical University, \\ Azenes iela 12/1, Riga, LV-1048, Latvia
}

\begin{abstract}
The European Union has placed competence-based teaching and competence-based education as one of its highly relevant goals. Due to mass higher education, the assessment of effectiveness and relevance evaluation of environmental engineering study programmes should become an important issue. Presently the focus of the evaluation on multi-disciplinary study programmes varies from the evaluation of attitudes, impacts or effectiveness of utilisation-focused evaluation, summative evaluation and participatory evaluation approaches. The objective of this study was to propose an effective framework to evaluate the Environmental Engineering Master study programmes. During the research, the evaluation of existing study programmes on environmental engineering in Europe was conducted, information about the study courses, teaching methods, assessment methods and competences was used for the analysis. The results obtained showed that lectures, site visits, group coursework, practical laboratories and role-plays allows to reach the necessary knowledge, skills and competences and to provide an effective and relevant education to the Environmental Engineering Master programme students. The proposed evaluation framework was tested and approbated on new Riga Technical University Master study programmes on Environmental Engineering and Bioeconomy.
\end{abstract}

Keywords - Assessment; bioeconomy; competence-based higher education; environmental engineering; indicators; internal quality management; MCA

\author{
Nomenclature \\ MCA Multi-Criteria Analysis \\ TOPSIS Technique for Order of Preference by Similarity to Ideal Solution \\ EE Environmental Education \\ CBE Competence-based education
}

\section{INTRODUCTION}

Environmental studies are becoming more and more popular in the last years; the evidence of this is, for example, a big number of articles in high-impact journals, a lot of project calls and projects, etc. [1]. New study programmes on bio-based circular economy, bioenergy, biofuels and bioproducts [2], clean energy [3], bioeconomy [4], [5] have been established and implemented recently.

Due to mass higher education, the assessment of effectiveness and relevance evaluation of EE study programmes should become an important issue. Scientists in different regions have

\footnotetext{
* Corresponding author.

E-mail address: jelena.pubule@rtu.lv
} 
been looking for ways to evaluate EE study programs in universities [1], [6]-[15]. The focus of evaluations on EE vary from the evaluation of attitudes, impacts or effectiveness to utilisation-focused evaluation, summative evaluations and participatory evaluation approaches [16], [17].

Higher education is one of the main indicators of global competitiveness and in the future due to globalization and knowledge transfer, modern masters programmes should have a multidisciplinary and interdisciplinary approach and be able to answer the demand of environmental engineering knowledge on a regional scale [18].

The European Union places competence-based teaching and competence-based education as one of its highly relevant goals. European Higher Education Area focused on the assuredness of comparability and compatibility of qualifications between graduates from different countries in the European Union. The "shift from teaching to learning" has been an influential factor in the development of new study programmes which include a shift from content-centred curricula to competence-centred curricula [19]-[21], putting employability as one of the main priorities. According to Oversberg et al. the current evaluation is based on quality measures focused on academic personnel, teaching methods and student satisfaction, instead of concentrating on the learning outcomes of the educational programmes.

In general, a competence-based education can help a student to deal with the challenges of the modern world: analyse data, be responsible, learn to learn and to make an appraisal based on a careful analytical evaluation. The main features and principles of a competence-based education (CBE) in higher education [21] are shown in Fig. 1. Based on the main features and principles, competence-based teaching involves working with knowledge, skills and attitudes.

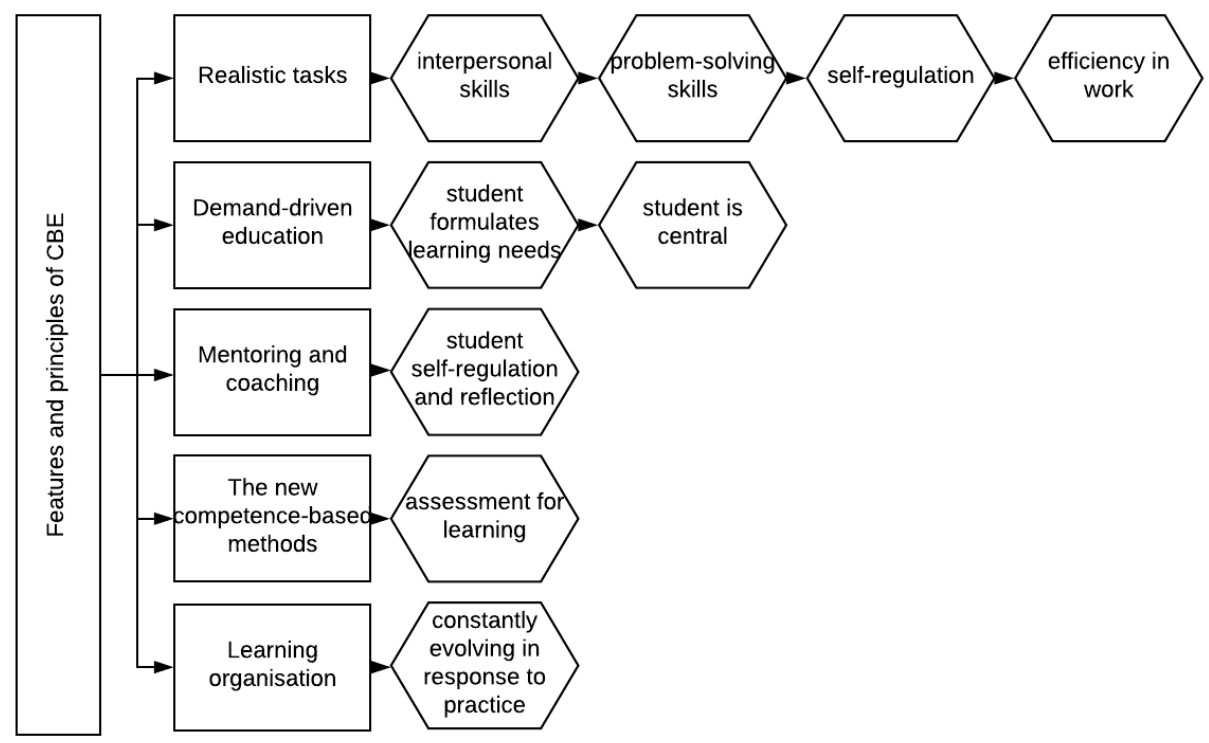

Fig. 1. Features and principles of CBE.

At the same time, there is no one single evaluation instrument for the evaluation of CBE in general and specifically in the evaluation of Environmental Engineering study programmes. 
In accordance with Bergsmann et al. [20], there are some main limitations of existing evaluation methods:

1. Main focus is laid on the competencies of the individual student;

2. Evaluation focus is on specific aspects of the teaching process;

3. Methods are based on status assessments, where the needs of stakeholders are not considered.

MCA is a well-known tool which has been used for the identification of different alternatives for solving complex questions, since this method allows selecting the best of different options. Mustafa [22] was the first scientist who described applying the multiple criteria decision-making method in higher education administration. Decades later, Ho et al. [23], used MCA to solve higher education decision problems, such as resource allocation, performance measurement, budgeting, and scheduling. Skordoulis et al. [24], used MCA for the analysis of student satisfaction. Basaran [25], analysed selecting and evaluating digital learning materials through multi criteria decision analysis approaches. Salomon et al. [26], described analysis of classrooms standardisation in higher education using MCA.

The proposed literature review highlights the lack of clear vision on evaluation methods for the assessment of the study programmes and the integration of MCA into the evaluation of competences.

Considering the results of the literature review, the main goal of this study is to propose a framework to evaluate the EE study programmes based on the use of MCA. This article consists of six parts. Part 2 observes the utility of MCA for the evaluation of EE study programmes and shows the pathway of the research step-by-step. Part 3 looks at EE programmes analysis in Europe. The results of the integration of MCA into evaluation and implementation of two new master study programmes on environmental engineering and bioeconomy are interpreted in Section 4. The results of MCA are analysed in Section 5 and overall conclusions are displayed and argued in Section 6.

\section{Methods AND Methodology}

The interest from students, stakeholders and society on the multidisciplinary master's programmes led to the decision to implement new master study programmes on Environmental Engineering and Bioeconomy in the Riga Technical University, Institute of Energy Systems and the Environment. To reach the objective of this study and to propose an effective framework to evaluate EE study programmes, the use of the MCA framework for the evaluation of study programme and assessment of effectiveness and relevance evaluation of environmental engineering study programmes has been developed.

The first part of the methodological algorithm is focused on identification and analysis of the existing situation and is based on literature review on teaching methods, assessment methods, competences and indicators used in evaluation and assessment of environmental engineering study programmes. In this stage the analysis of regulations and legislative framework, as well as analysis of results of survey on EE education in Europe have been conducted. The second step is definition of the issue, objective and scope of the study programme, which follows by identification and selection of the most significant indicators and definition of key factors influencing the shift to CBE. Taken into account key factors, the definition of teaching methods, skills, knowledge, assessment methods and competences are defined. 
To find and evaluate the optimal teaching methods combination, TOPSIS (the Technique for Order of Preference by Similarity to Ideal Solution) was applied. The MCA method dwells mostly on a weighted set of criteria.

During the MCA process, the multi-objective matrix has been optimized. The criteria identified within are reduced into a single-score measure using a weighting procedure that determines relative importance by multiplying each criterion with a weighing factor.

Qualitative and quantitative analysis of Environmental Engineering study programmes: core competences, indicators, skills, knowledge, desirable outcomes, teaching methods and assessment methods using CBE concepts and features have been conducted.

The basic approach is established within the scheme presented as Fig. 2.

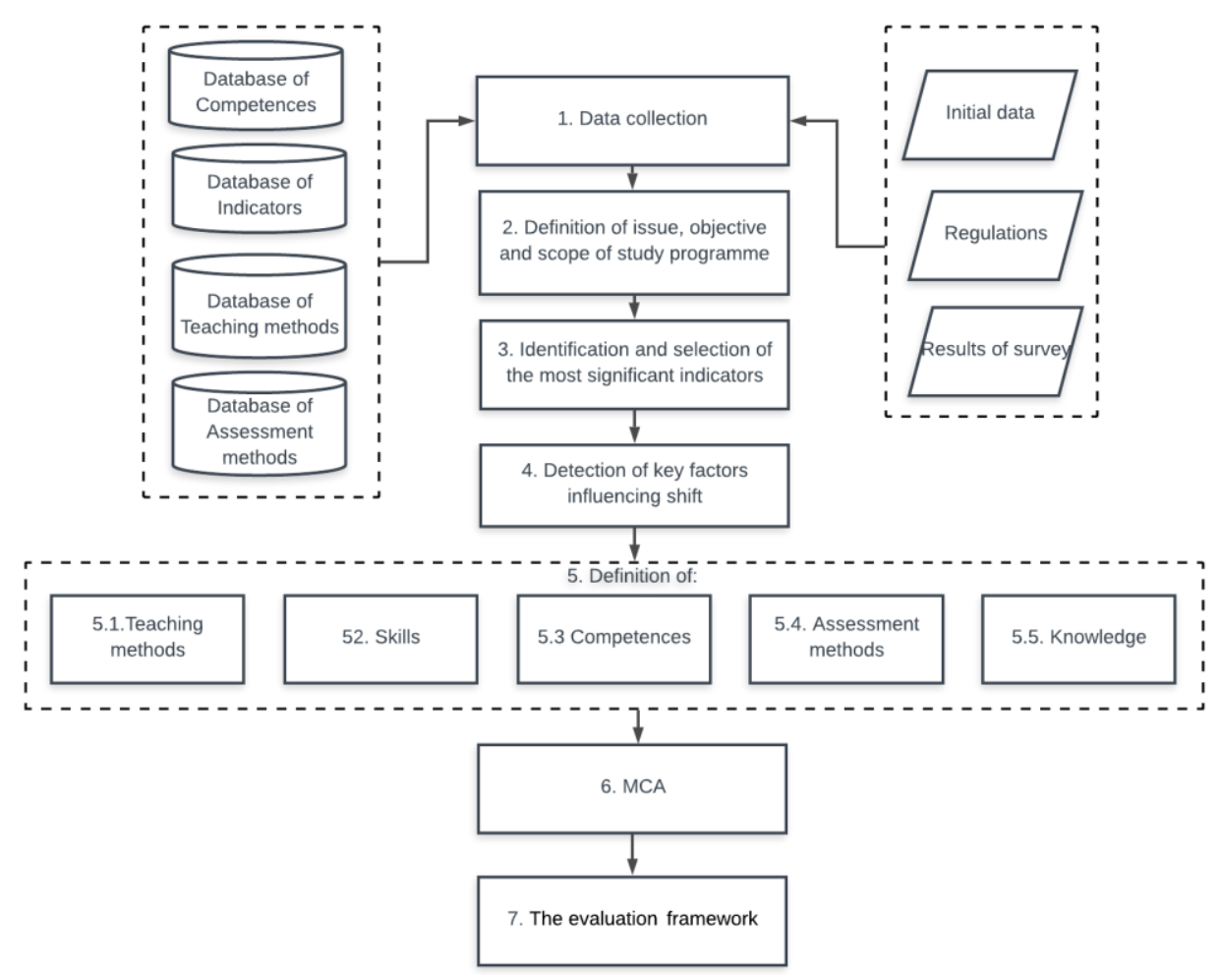

Fig. 2. Overall methodological scheme.

\section{EE Programme AnAlysis in Europe}

The work started with the survey on EE Master study programmes conducted by European Universities. Geographical location - Europe was chosen because of similar education systems between different universities in the region. The focus of this study was to analyse good practice in EE, therefore academic institutions with excellent performance were investigated. Ranking websites [27], [28] were used for the selection of study programmes for the study. In total 110 study programmes were analysed. As the objective of the research was the evaluation of existing masters programmes in environmental engineering, 35 study 
programmes were selected for the evaluation. The selected multi-disciplinary masters study programmes comprise of masters programmes from the fields of Environmental Engineering (22 study programmes), Water and Waste Management (3 study programmes), Environmental Technologies (2 study programmes), Environmental Science (2 study programmes), Land Planning Engineering, Project Management, Biological Engineering, Energy Engineering and Bioeconomy (see Table 1). To be able to use the best practices, masters programmes performing highly in the QS Global World Ranking by QS Quacquarelli Symonds were examined. Ten of the analyzed study programmes are ranked in the top-100, twelve between 100 and 200, three between 200 and 300, six between 300 and 400, two between 400 and 500 and two between 500 and 600. The study length degree is one (13 of 35 study programmes), one and a half ( 2 study programmes) or two (20 study programmes) full time years.

TABle 1. MULTI-DisCIPLINARY STUDY PROGRAMMES ON ENVIRONMENTAL ENGINEERING

\begin{tabular}{|c|c|c|c|}
\hline University & Master programme & Ranking & Years \\
\hline ETH Zurich & Environmental Engineering & 3 & 2 \\
\hline Delft University of Technology & Environmental Engineering & 16 & 2 \\
\hline Technical University of Denmark & Environmental Engineering & 45 & 2 \\
\hline TUM - Technical University of Munich & Environmental Engineering & 61 & 2 \\
\hline University of Nottingham & Environmental Engineering & 82 & 1 \\
\hline Trinity College Dublin & Environmental Engineering & 104 & 1 \\
\hline Aalto University & Environmental Engineering & 140 & 2 \\
\hline Newcastle University & Environmental Engineering & 141 & 2 \\
\hline Universitat de Barcelona & Environmental Engineering & 166 & 1 \\
\hline University of Bologna & Environmental Engineering & 180 & 2 \\
\hline Queen's University Belfast & Environmental Engineering & 180 & 1 \\
\hline Cranfield University & Environmental Engineering & $251-300$ & 1 \\
\hline Universität Stuttgart & Environmental Engineering & 260 & 2 \\
\hline Universitat Politècnica de Catalunya & Environmental Engineering & 275 & 2 \\
\hline Universitat Politècnica de València & Environmental Engineering & 310 & 1 \\
\hline Czech Technical University in Prague & Environmental Engineering & 317 & 2 \\
\hline University of Porto & Environmental Engineering & 328 & 1 \\
\hline University of Lisbon & Environmental Engineering & 355 & 2 \\
\hline $\begin{array}{l}\text { Norwegian University of Science And } \\
\text { Technology }\end{array}$ & Environmental Engineering & 363 & 2 \\
\hline Universidad Politécnica de Madrid & Environmental Engineering & 470 & 1 \\
\hline Universität Bremen & Environmental Engineering & $511-520$ & 1.5 \\
\hline Universidade de Santiago de Compostela & Environmental Engineering & $581-590$ & 1.5 \\
\hline KTH Royal Institute of Technology & $\begin{array}{l}\text { Environmental Engineering and Sustainable } \\
\text { Infrastructure }\end{array}$ & 104 & 2 \\
\hline Ghent University & Environmental Technology and Engineering & 138 & 2 \\
\hline $\begin{array}{l}\text { University of Natural Resources and } \\
\text { Applied Life Sciences Vienna }\end{array}$ & $\begin{array}{l}\text { Water Management and Environmental } \\
\text { Engineering }\end{array}$ & $151-200$ & 2 \\
\hline Politecnico di Milano & Environmental and Land Planning Engineering & 156 & 2 \\
\hline
\end{tabular}




\begin{tabular}{lllc}
\hline University & Master programme & Ranking & Years \\
\hline Universitat Autònoma de Barcelona & Biological and Environmental Engineering & 193 & 1 \\
University College Dublin & Water, Waste \& Environmental Engineering & 193 & 1 \\
Aalborg University & Water and Environmental Engineering & 343 & 2 \\
University of Hohenheim & Bioeconomy & 495 & 2 \\
\hline
\end{tabular}

For the evaluation of existing study programmes, information about study courses, teaching methods, assessment methods and competences were used. Based on this information, the set of competences, indicators, skills, assessment methods, knowledge, teaching methods for the evaluation of Environmental engineering masters study programmes was elected.

\section{USE OF MCA FOR IMPLEMENTATION AND EVALUATION OF STUDY Programmes}

\subsection{Environmental Engineering Study Programmes' Evaluation Indicators}

For the definition of Environmental Engineering Programme indicators, the indicators from existing research published in scientific journals for the mapping of environmental education programmes in higher education were analysed.

During the research, five indicators were found to be suitable for the evaluation of environmental engineering study programmes:

1. Multidisciplinary approach;

2. Cooperation with other institutions;

3. Internal process;

4. Education and research;

5. Simulation activities [7].

Multidisciplinary approach has a very important role in environmental engineering, since students need to solve complex problems within study programme with different stakeholders' interests and by interacting among various interests. An interdisciplinary research is highly valuated in leading universities, helps students to develop critical thinking and creativity [29], [30]. At the same time, the balance between multi- and interdisciplinarity and in deep knowledge of different courses must be taken into consideration [31].

Cooperation with other institutions can be organized through research projects, common (joint or double) study programmes. Cooperation allows the sharing of knowledge, experiences and capacities [32], [33]. A lot of universities offer common study programmes for EE, for example, Nordic masters in environmental engineering, in cooperation with Aalto University, KTH Royal Institute of Technology, Technical University of Denmark, Norwegian University of Science and Technology and Chalmers University of Technology, whereby 5 universities from one region are cooperating with each other. Another example is cooperation between University of Valencia and Universitat Politècnica de València, where a joint masters in environmental engineering is offered.

An internal process through adoption of environmental management strategies, providing and understanding of environmental issues and sustainable development in universities can be introduced [34].

Education and research are the basic of higher educational institutions, therefore the research outcomes should be analysed. 
Simulation activities and practical learning allows to reach the best outcomes in study programmes, allowing for the introduction of competence-based education into the agenda.

These five indicators (multidisciplinary approach, cooperation with other institutions, internal process, education and research and simulation activities) can help to evaluate if the knowledge triangle: education-innovation-research, as well as competence-based education have been achieved.

European Network for Accreditation of Engineering Education (EUR-ACE) is a framework and accreditation system that provides a set of standards for engineering degree programmes in Europe and beyond. The sets of learning outcomes for environmental engineering masters programmes are shown in Table 2.

\section{TABLE 2. LEARNING OUTCOMES WITHIN EUR-ACE [35]}

\begin{tabular}{ll}
\hline Areas & Learning outcomes \\
\hline $\begin{array}{l}\text { Knowledge and } \\
\text { understanding }\end{array}$ & $\begin{array}{l}\text { Knowledge and understanding of the scientific and mathematical principles underlying their } \\
\text { branch of engineering } \\
\text { Systematic understanding of the key aspects and concepts of their branch of engineering } \\
\text { Coherent knowledge of their branch of engineering including some at the forefront of the } \\
\text { branch } \\
\text { Awareness of the wider multidisciplinary context of engineering }\end{array}$ \\
\hline $\begin{array}{l}\text { Engineering } \\
\text { analysis }\end{array}$ & $\begin{array}{l}\text { Ability to apply their knowledge and understanding to identify, formulate and solve } \\
\text { engineering problems using established methods } \\
\text { Ability to apply their knowledge and understanding to analyse engineering products, processes } \\
\text { and methods }\end{array}$ \\
Ability to select and apply relevant analytic and modelling methods \\
\hline $\begin{array}{l}\text { Engineering } \\
\text { design }\end{array}$ & $\begin{array}{l}\text { Ability to apply their knowledge and understanding to develop and realise designs to meet } \\
\text { defined and specified requirements } \\
\text { Understanding of design methodologies, and ability to use them }\end{array}$ \\
\hline Investigations & $\begin{array}{l}\text { Ability to conduct searches of literature, and to use data bases and other sources of information } \\
\text { Ability to design and conduct appropriate experiments, interpret the data and draw learning } \\
\text { skills workshop and laboratory skills } \\
\text { Workshop and laboratory skills }\end{array}$ \\
\hline
\end{tabular}

Engineering

practice
Ability to select and use appropriate equipment, tools and methods

Ability to combine theory and practice to solve engineering problems

Understanding of applicable techniques and methods, and of their limitations

Awareness of the non-technical implications of engineering practice

Transferable skills Function effectively as an individual and as a member of a team

Use diverse methods to communicate effectively with the engineering community and with society at large

Demonstrate awareness of the health, safety and legal issues and responsibilities of engineering practice, the impact of engineering solutions in a societal and environmental context, and commit to professional ethics, responsibilities and norms of engineering practice

Demonstrate an awareness of project management and business practices, such as risk and change management, and understand their limitations 


\subsection{Competences}

The main competences which should be reached at the end of the studies can be divided into 4 categories. These are:

1. Subject-related competences;

2. Scientific and methodological competences;

3. Social competences;

4. Personal competences [19].

The degree to which students need to reach the respective knowledge at the end of the study programme should correspond to expansion level, see Table 3. At the end of the study programme students should reach certain cognitive aspects, as a) test specific research questions and b) make contribution to research, and practical aspects, as well as a) develop certain techniques and $b$ ) test certain techniques.

TABLE 3. COMPETENCE LEVELS [19]

\begin{tabular}{lllllll}
\hline Level 0 & Level 1 & Level 2 & Level 3 & Level 4 & Level 5 & Level 6 \\
\hline No knowledge & Threshold & Foundation & Interconnection & Contextualization & Expansion & Generation \\
\hline
\end{tabular}

To reach these competences and knowledge degree different teaching methods can be used. To evaluate which teaching methods are more suitable for environmental engineering studies, MCA was applied.

\section{RESUlts}

During the research, the experience in the organization of study programmes of the previously mentioned universities were analysed. As a result of the research, thirteen teaching methods were found to be suitable to reach the best results in the study process and to provide a competence-based environmental engineering education for the masters study level: anonymous feedback evaluations, united e-learning system (intranet), field data collection, group coursework, group exercises, individual research project, lectures, online assignments and coursework, practical laboratories, seminars and workshops, site visits, tutorials and role-plays.

These teaching methods have been used in undergraduate and postgraduate study programmes during the study process at the Riga Technical University, Institute of Energy Systems and Environment (RTU IESE).

The teaching methods selected for the educational purposes have a significant impact on effectiveness of the study process [36]-[41] and obtained skills.

Anonymous feedback evaluation, as well as direct feedback [42] from students can be a useful and effective method for the improvement of the study process, especially in CBE, where students can formulate their study needs and lead to better results in the study process.

United e-learning system (intranet), in the case of the Riga Technical University it is ORTUS multifunctional higher education establishment website, is essential in CBE, since if used comprehensively, can lead to strongest improvements in student's flexibility and can help to develop creative thinking [43], [44].

Group work organized in the form of coursework or group exercises, develop personal and social competences, understanding of team work, stimulate a multidisciplinary concept, etc. [45].

Use of site visits and field data collection, seminars and workshops and practical laboratories allows to introduce CBE features [45] and concepts in the teaching process. Lectures and tutorials together with individual research projects are an indispensable part of 
any higher education process, but not the only one. Lectures and tutorials form just a part of the teaching methods which should be used in the study process.

Role-play simulations develop core competences for environmental engineering study programme students and in general have been considered to be rich and authentic learning environments [45]. The combination of these teaching methods can help to change the pathway from teaching to learning and provide CBE principles in study process.

\subsection{Indicators}

In MCA four indicators were developed to analyse the following competences: engineering skills, transferable skills, environmental protection skills and socio-economic skills. The aim of MCA was to evaluate which teaching methods are more suitable and in which proportions to enhance core competences for the environmental engineering masters programme graduates. The indicated indicators were elaborated by evaluating the literature and assembling the assessment of academic staff in the sector. The indicators used in MCA for the assessment of teaching methods appraisal are shown in Table 4.

\section{TABLE 4. INDICATORS USED FOR THE ASSESSMENT OF TEACHING METHODS APPRAISAL}

\begin{tabular}{lll}
\hline Indicator & Unit & Preferable outcome \\
\hline Engineering skills & Competence level & Max \\
Transferable skills & Competence level & Max \\
$\begin{array}{l}\text { Environmental protection } \\
\text { skills }\end{array}$ & Competence level & Max \\
Socioeconomical skills & Competence level & Max \\
\hline
\end{tabular}

During the research, thirteen teaching methods were appraised and compared for the sake of finding the most effective methods for the achievement of the best results in the study process (Table 5).

\section{TABLE 5. DEsignation OF TEACHING MethodS}

\begin{tabular}{ll}
\hline Designation & Environmental engineering teaching methods \\
\hline $\mathrm{A}_{1}$ & Anonymous feedback evaluations \\
$\mathrm{A}_{2}$ & United e-learning system (intranet) \\
$\mathrm{A}_{3}$ & Field data collection \\
$\mathrm{A}_{4}$ & Group coursework \\
$\mathrm{A}_{5}$ & Group exercises \\
$\mathrm{A}_{6}$ & Individual research project \\
$\mathrm{A}_{7}$ & Lectures \\
$\mathrm{A}_{8}$ & Online assignments and coursework \\
$\mathrm{A}_{9}$ & Practical laboratories \\
$\mathrm{A}_{10}$ & Seminars and Workshops \\
$\mathrm{A}_{11}$ & Site Visits \\
$\mathrm{A}_{12}$ & Tutorials \\
$\mathrm{A}_{13}$ & Role-plays \\
\hline
\end{tabular}


Criteria weights $\left(w_{1} b_{i 1}, w_{2} b_{i 2}, w_{3} b_{i 3}, w_{3} b_{i 3}\right)$ were evaluated by RTU IESE experts. Normalized and weighted values from the decision-making matrix for the evaluation of teaching methods are displayed in Table 6.

TABle 6. NORMALIZED AND WeIGHTED DECISION-MAKING MATRIX

\begin{tabular}{lllll}
\hline \multicolumn{1}{|c}{ Criterion } & $\begin{array}{l}\text { Engineering } \\
\text { skills }\end{array}$ & $\begin{array}{l}\text { Transferable } \\
\text { skills }\end{array}$ & $\begin{array}{l}\text { Environmental } \\
\text { protection skills }\end{array}$ & $\begin{array}{l}\text { Socio-economic } \\
\text { skills }\end{array}$ \\
\hline $\mathbf{A}_{\mathbf{1}}$ & $w_{1} b_{i 1}$ & $w_{2} b_{i 2}$ & $w_{3} b_{i 3}$ & $w_{3} b_{i 3}$ \\
$\mathbf{A}_{\mathbf{2}}$ & 0.0015625 & 0.005625 & 0.003125 & 0.00375 \\
$\mathbf{A}_{\mathbf{3}}$ & 0.0046875 & 0.00375 & 0.003125 & 0.00375 \\
$\mathbf{A}_{\mathbf{4}}$ & 0.0078125 & 0.001875 & 0.00625 & 0.00125 \\
$\mathbf{A}_{\mathbf{5}}$ & 0.00625 & 0.0075 & 0.00625 & 0.005 \\
$\mathbf{A}_{\mathbf{6}}$ & 0.0046875 & 0.0075 & 0.0046875 & 0.005 \\
$\mathbf{A}_{\mathbf{7}}$ & 0.00625 & 0.005625 & 0.0046875 & 0.00375 \\
$\mathbf{A}_{\mathbf{8}}$ & 0.0078125 & 0.0075 & 0.0078125 & 0.00625 \\
$\mathbf{A}_{\mathbf{9}}$ & 0.003125 & 0.00375 & 0.0015625 & 0.0025 \\
$\mathbf{A}_{\mathbf{1 0}}$ & 0.0078125 & 0.005625 & 0.0078125 & 0.005 \\
$\mathbf{A}_{\mathbf{1 1}}$ & 0.003125 & 0.009375 & 0.0046875 & 0.00625 \\
$\mathbf{A}_{\mathbf{1 2}}$ & 0.00625 & 0.009375 & 0.00625 & 0.0025 \\
$\mathbf{A}_{13}$ & 0.0015625 & 0.009375 & 0.0078125 & 0.00625 \\
\hline
\end{tabular}

The teaching methods evaluation using TOPSIS were completed for masters study programme on Environmental Engineering.

The results obtained showed that lectures $\left(A_{7}\right)$, site visits $\left(A_{11}\right)$, group coursework $\left(A_{4}\right)$ and practical laboratories $\left(A_{9}\right)$ together with role-plays $\left(A_{13}\right)$ allows to reach necessary knowledge, skills and competences (Fig. 3). 


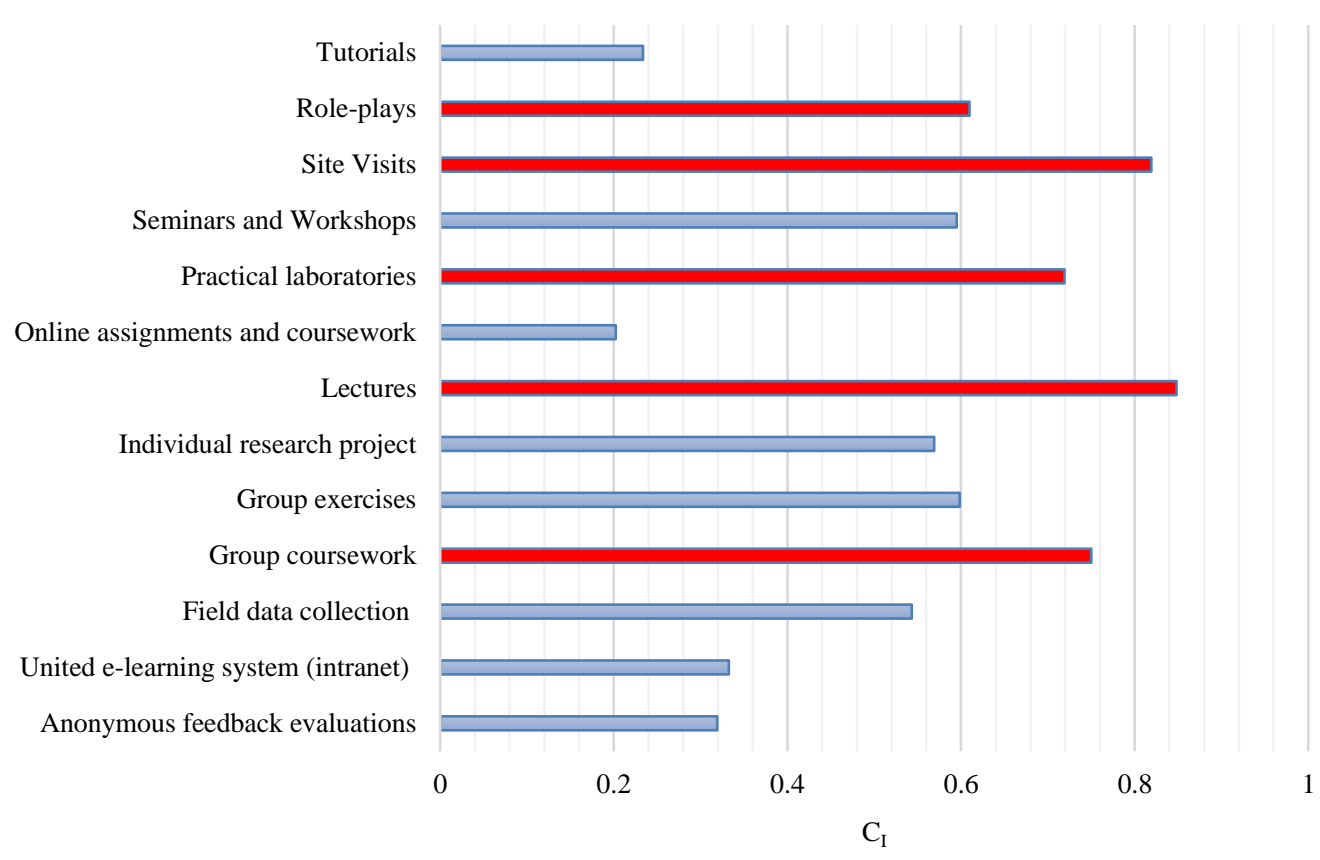

Fig. 3. Comparison of teaching methods ratings.

As assessment methods for group exercises, group course assignments can be used, for group coursework group projects and presentations, individual coursework assignments for the individual research projects should be used. For the individual research projects, individual coursework assignment can allow to evaluate the work. Research dissertations and written examinations are an effective tool in the assessment of individual work.

The assessment framework for the evaluation of environmental engineering study programme was developed (Fig. 4).

The proposed assessment framework for the evaluation of environmental engineering study programme was tested and approbated on new Riga Technical University masters study programmes on Environmental Engineering and Bioeconomy. 


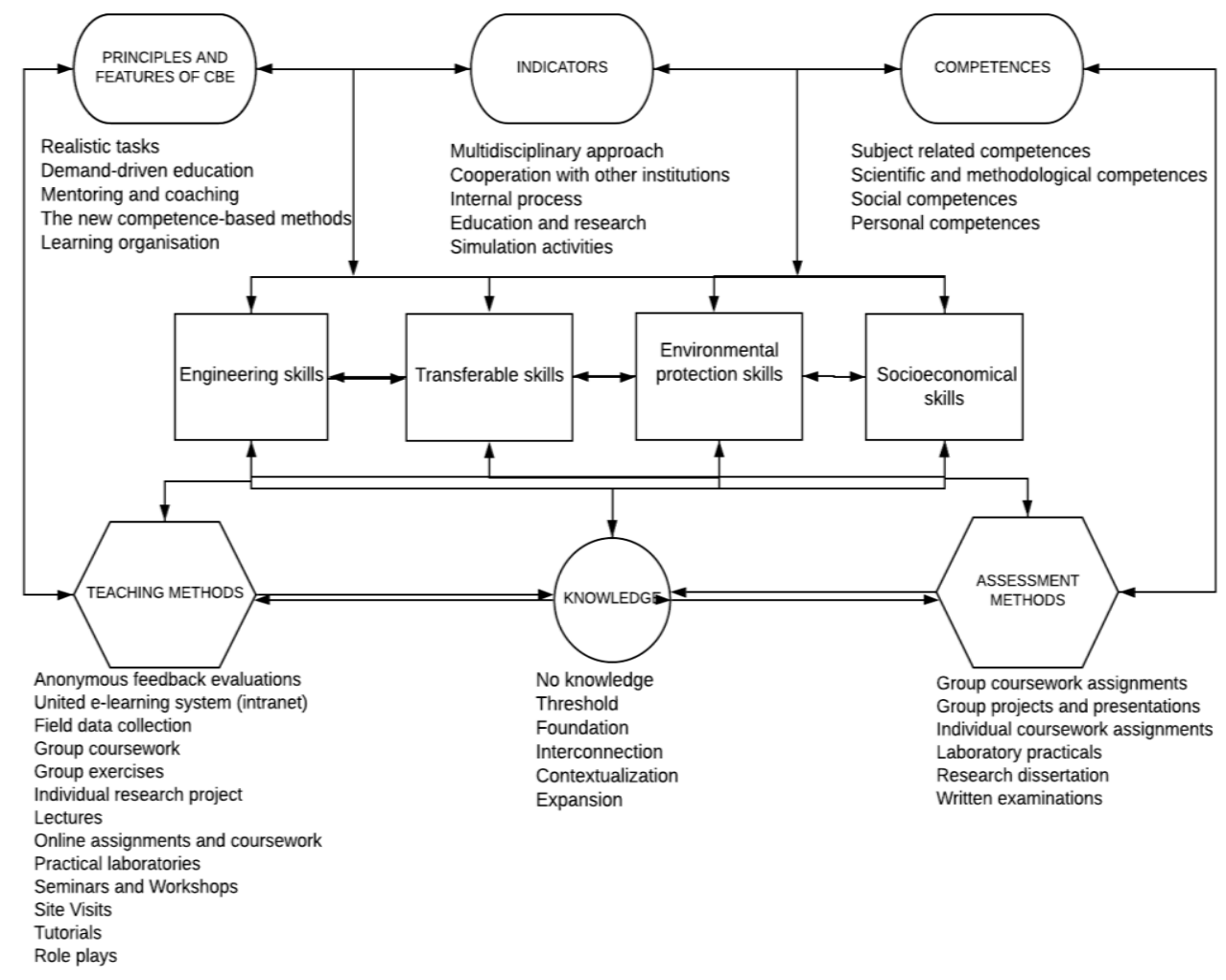

Fig. 4. Assessment framework for the evaluation of environmental engineering study programme. 


\section{Conclusions}

The overall objective of this study was to propose a compelling scheme of the evaluation of the environmental engineering masters study programme.

During the research, the evaluation of existing study programmes on environmental engineering in Europe were analysed, information about study courses, teaching methods, assessment methods and competences were used for the analysis. The results obtained showed that lectures, site visits, group coursework, practical laboratory work and role play allows to reach necessary knowledge, skills and competences and provide effective and relevant education to Environmental Engineering Masters programme students.

The core competences (subject-related competences, scientific and methodological competences, social competences and personal competences) were determined to assure quality measures of study process. This process is related with the use of five evaluation indicators (multidisciplinary approach, cooperation with other institutions, internal process, education and research and simulation activities), which allows to evaluate programme learning outcomes.

Thirteen learning methods (anonymous feedback evaluations, united e-learning system (intranet), field data collection, group coursework, group exercises, individual research projects, lectures, online assignments and coursework, practical laboratory work, seminars and workshops, site visits, tutorials and role-plays) suitable for the environmental engineering studies were selected, evaluated and compared in order to find the most effective methods for the achievement of the best results in the study process. The results of MCA defined that that lectures, site visits, group coursework and practical laboratories together with role-plays simulations should engage the major part of study process.

Developed assessment framework can be used during the development process of new environmental engineering study programmes and for the evaluation of the existing study programmes with a similar profile. Future research based on the results of this study should include sensitivity analysis and deeper investigation on CBE outcomes, as well as determination of bottlenecks for the effective transfer of given information to competencebased knowledge.

\section{REFERENCES}

[1] Romero-Gutierrez M., Jimenez-Liso M. R., Martinez-Chico M. SWOT analysis to evaluate the programme of a joint online/onsite master's degree in environmental education through the students' perceptions. Evaluation and Program Planning 2016:54:41-49. doi:10.1016/j.evalprogplan.2015.10.001

[2] Nibbi L., Chiaramonti D., Palchetti E. Project BBChina: a new Master Program in three Chinese Universities on Bio-Based Circular Economy; from Fields to Bioenergy, Biofuel and Bioproducts. Energy Procedia 2019:158:1261-1266. doi:10.1016/j.egypro.2019.01.416

[3] Anany M. N., Shehadeh M. F., Álvarez Peña C. Design of a New Egyptian/European Double Master Degree in Clean Energy and Environmental Studies. Energy Procedia 2013:36:408-417. doi:10.1016/j.egypro.2013.07.047

[4] Takala T., et al. Shaping the concept of bioeconomy in participatory projects - An example from the post-graduate education in Finland. Journal of Cleaner Production 2019:221:176-188. doi:10.1016/j.jclepro.2019.02.007

[5] University of Hohenheim. Degree Program: Bioeconomy [Online]. [Accessed 30.03.2019]. Available: https://www.uni-hohenheim.de/en/bioeconomy-masters

[6] Trencher G., et al. Evaluating core competencies development in sustainability and environmental master's programs: An empirical analysis. Journal of Cleaner Production 2018:181:829-841. doi:10.1016/j.jclepro.2018.01.164

[7] Andrade Guerra J. B. S. O., et al. A proposal of a balanced scorecard for an environmental education program at universities. Journal of Cleaner Production 2018:172:1674. doi:10.1016/j.jclepro.2016.11.179

[8] Miñán E., Lavalle C., Díaz-Puente J. M. Relevance Evaluation of Engineering Master's Program in Peru. Procedia Social and Behavioral Sciences 2012:46:1557-1564. doi:10.1016/j.sbspro.2012.05.340 
[9] Celik F. Comparing distance education versus traditional education in Engineering Management Masters Program: Sakarya University Sample. IFAC-PapersOnLine 2016:49(29):305-309. doi:10.1016/j.ifacol.2016.11.084

[10] Aznar Minguet P., Martinez-Agut M. P., Palacios B., Piñero A., Ull M. A. Introducing sustainability into university curricula: An indicator and baseline survey of the views of university teachers at the University of Valencia. Environmental Education Research 2011:17(2):145-166. doi:10.1080/13504622.2010.502590

[11] Bowe A. G. The development of education indicators for measuring quality in the English-speaking Caribbean: How far have we come? Evaluation and Program Planning 2015:48:31-46. doi:10.1016/j.evalprogplan.2014.08.008

[12] Goldman D., Yavetz B., Pe'er S. Environmental literacy in teacher training in Israel: Environmental behavior of new students. The Journal of Environmental Education 2006:38(1):3-22. doi:10.3200/JOEE.38.1.3-22

[13] Hurlimann A. C. Responding to environmental challenges: An initial assessment of higher education curricula needs by Australian planning professionals. Environmental Education Research 2009:15(6):643-659. doi:10.1080/13504620903244159

[14] Van Petegem P., Blieck A., Boeve-De Pauw J. Evaluating the implementation process of environmental education in preservice teacher education: Two case studies. The Journal of Environmental Education 2007:38(2):47-54. doi:10.3200/JOEE.38.1.47-54

[15] Wesselink R., Wals A. E. J. Developing competence profiles for educators in environmental education organisations in the Netherlands. Environmental Education Research 2011:17(1):69-90. doi:10.1080/13504621003637037

[16] Carleton-Hug A., Hug J. W. Challenges and opportunities for evaluating environmental education programs. Evaluation and Program Planning 2010:33(2):159-164. doi:10.1016/j.evalprogplan.2009.07.005

[17] Stern M. J., Powell R. B., Hill D. Environmental education program evaluation in the new millennium: What do we measure and what have we learned? Environmental Education Research 2014:20(5):581-611. doi:10.1080/13504622.2013.838749

[18] Beynaghi A., et al. Future sustainability scenarios for universities: moving beyond the United Nations Decade of Education for Sustainable Development. Journal of Cleaner Production 2016:112(4):3464-3478 doi:10.1016/j.jclepro.2015.10.117

[19] Overberg J., et al. Internal quality management in competence-based higher education - An interdisciplinary pilot study conducted in a postgraduate programme in renewable energy. Solar Energy 2019:177:337-346. doi:10.1016/j.solener.2018.11.009

[20] Bergsmann E., Schultes M. T., Winter P., Schober B., Spiel C. Evaluation of competence-based teaching in higher education: From theory to practice. Evaluation and Program Planning 2015:52:1-9. doi:10.1016/j.evalprogplan.2015.03.001

[21] Koenen A. K., Dochy F., Berghmans, I. A phenomenographic analysis of the implementation of competence-based education in higher education. Teaching and Teacher Education 2015:50:1-12. doi:10.1016/j.tate.2015.04.001.

[22] Mustafa A., Goh M. Multi-criterion models for higher education administration. Omega 1996:24(2):167-178. doi:10.1016/0305-0483(95)00053-4

[23] Ho W., Dey P.K., Higson H. E. Multiple Criteria Decision Making Techniques in Higher Education. International Journal of Educational Management 2006:20:319-337. doi:10.1108/09513540610676403

[24] Skordoulis M., Drosos D., Mandalenaki M. An Analysis of Students' Satisfaction Using a Multicriteria Method. Proceedings of 2nd International Conference on Lifelong Education and Leadership for ALL-ICLEL. 2016:401-412.

[25] Başaran S. Multi-Criteria Decision Analysis Approaches for Selecting and Evaluating Digital Learning Objects. Procedia Computer Science 2016:102:251-258. doi:10.1016/j.procs.2016.09.398

[26] Salomon V. A. P., Alonso P. J., Marins S. F. A. Multi-criteria decision analysis of classrooms standardisation in a higher education institution. International Journal of Business and Systems Research 2016:10(2/3/4):394-402. doi:10.1504/IJBSR.2016.075756.

[27] QS World University Rankings [Online]. [Accessed 31.03.2019]. Available: https://www.topuniversities.com/

[28] Ranking WEB of Universities [Online]. [Accessed 31.03.2019]. Available: http://www.webometrics.info/en

[29] Azeiteiro U. M., Bacelar-Nicolau P., Caetano F. J. P., Caeiro S. Education for sustainable development through e-learning in higher education: experiences from Portugal. Journal of Cleaner Production 2015:106:308-319. doi:10.1016/j.jclepro.2014.11.056

[30] Nowotny J., et al. Towards global sustainability: Education on environmentally clean energy technologies. Renewable and Sustainable Energy Reviews 2018:81(2):2541-2551. doi:10.1016/j.rser.2017.06.060

[31] Zuo Z., Zhao K. The more multidisciplinary the better? - The prevalence and interdisciplinarity of research collaborations in multidisciplinary institutions. Journal of Informetrics 2018:12(3):736-756. doi:10.1016/j.joi.2018.06.006

[32] Filho W. L., Shiel C., Paço P. Implementing and operationalising integrative approaches to sustainability in higher education: the role of project-oriented learning. Journal of Cleaner Production 2016:133:126-135. doi:10.1016/j.jclepro.2016.05.079

[33] Adomßent M., et al. Emerging areas in research on higher education for sustainable development - management education, sustainable consumption and perspectives from Central and Eastern Europe. Journal of Cleaner Production 2014:62:1-7. doi:10.1016/j.jclepro.2013.09.045 
[34] Freidenfelds D., Kalnins S. N., Gusca J. What does environmentally sustainable higher education institution mean? Energy Procedia 2018:147:42-47. doi:10.1016/j.egypro.2018.07.031

Caporali E., Catelani M., Manfrida G., Valdiserri J. Accreditation of Environmental Engineering Education at the School of Engineering, University of Firenze (Italy). Conference paper from $2^{\text {nd }}$ ENAEE annual conference. [Online] [Accessed 31.03.2019]. Available: https://www.enaee.eu/wp-assets-enaee/uploads/2012/01/AUGUST-Paper-130628.pdf

[35] Yakovleva N. O., Yakovlev E. V. Interactive teaching methods in contemporary higher education. Pacific Science Review 2014:16(2):75-80. doi:10.1016/j.pscr.2014.08.016

[36] Valderrama-Hernández R., Alcántara L., Limón D. The Complexity of Environmental Education: Teaching Ideas and Strategies from Teachers. Procedia - Social and Behavioral Sciences 2017:237:968-974. doi:10.1016/j.sbspro.2017.02.137

[37] Grizans J., Vanags J. Possibilities of the Integration of the Method of the Ecologically Oriented Independent Scientific Research in the Study Process. Environmental and Climate Technologies 2011:5(1):42-48. doi:10.2478/v10145-010-0033-4

[38] Romagnoli F., Blumberga D. Teaching Applied Geophysics at RTU: The Basics for a Fast, Green, Inexpensive Subground Investigation Method. Environmental and Climate Technologies 2011:5(1):91-97. doi:10.2478/v10145-010-0040-5

[39] Svirina A., Shindor, O., Tatmyshevsky K. Development Of Educational Programs In Renewable And Alternative Energy Processing: The Case Of Russia. Environmental and Climate Technologies 2014:13(1):20-26. doi:10.2478/rtuect-2014-0003

[40] Malkki H., Alanne K., Hirsto L. Energy engineering students on their way to expertise in sustainable energy. Environmental and Climate Technologies 2012:8:24-28. doi:10.2478/v10145-012-0004-z

[41] Corelli A. Direct vs. Anonymous Feedback: Teacher Behavior in Higher Education, with Focus on Technology Advances. Procedia - Social and Behavioral Sciences 2015:195:52-61. doi:10.1016/j.sbspro.2015.06.329

[42] Songkram N. E-learning System in Virtual Learning Environment to Develop Creative Thinking for Learners in Higher Education. Procedia - Social and Behavioral Sciences 2015:174:674-679. doi:10.1016/j.sbspro.2015.01.600

[43] Jia X., Hu W., Cai F., Wang H, Li J., Runco M.A., Chen Y. The influence of teaching methods on creative problem finding. Thinking Skills and Creativity 2017:24:86-94. doi:10.1016/j.tsc.2017.02.006

[44] Duchatelet D., Gijbels D., Bursens P., Donche V., Spooren P. Looking at role-play simulations of political decision-making in higher education through a contextual lens: A state-of-the-art. Educational Research Review 2019:27:126-139. doi:10.1016/j.edurev.2019.03.002

[45] Wijnia L., Kunst E.M., Woerkom M. van., Poell, R.F. Team learning and its association with the implementation of competence-based education. Teaching and Teacher Education 2016:56:115-126. doi.org/10.1016/j.tate.2016.02.006. 